\title{
CONSTITUTIONAL LAW NORM: SOME ASPECTS OF STRUCTURE
}

\section{НОРМА КОНСТИТУЦІЙНОГО ПРАВА: ДЕЯКІ АСПЕКТИ СТРУКТУРИ}

\author{
Dmytro Bielov \\ Doctor of Law, Professor, \\ Department of Constitutional Law and Comparative Law, \\ SHEI Uzhhorod National University \\ ORCID: 0000-0002-7168-9488 \\ Myroslava Hromovchuk \\ Doctor of Law, \\ associate professor of the Department of Constitutional \\ Law and Comparative Law \\ SHEI Uzhhorod National University, \\ ORCID: 0000-0003-2077-2342
}

Бєлов Д. М. доктор юридичних наук, професор, кафедра конституційного права та порівняльного правознавства, ДВНЗ УжНУ

Громовчук М. В. доктор юридичних наук, доцент кафедри конституційного права та порівняльного правознавства ДВНЗ УжНУ

The specifics of the norm of the constitutional law of Ukraine in the context of enshrining in it the basic provisions of the constitutional and legal status of a person and a citizen are revealed. It is pointed out that the multifaceted system of constitutional law of Ukraine and all its structural elements consist of the norms of constitutional law. The latter are the basis of the institutions of constitutional law, as well as other parts of the system of constitutional law - natural and positive, general and special part, substantive and procedural, international and national, and so on. That is, the system of constitutional law of Ukraine cannot exist outside its normative dimension. In addition, law, and later its system, were formed on the basis of legal norms, which have historically stood out from other social norms - religious, moral, ethical, cultural, and so on. It is noted that the position of the general theory of constitutional law, the study of the constitutional and legal status of man and citizen is closely related to the problem of determining the subject of constitutional law on the legal status of man and citizen. In this sense, in the science of constitutional law, there are at least two ways to answer the question. One of them as a subject of constitutional law interprets only the basic principles of the constitutional and legal status of man, and the other to the subject of the science of constitutional law also adds the problems of protection and maintenance of the constitutional and legal status of man and citizen. On the other hand, the coverage of the problems of the constitutional and legal status of man and citizen has a purely methodological relevance. The establishment of the foundations of the legal status of a person by the Constitution of Ukraine marked the beginning of the process of compiling a new type of legal culture of our state and its citizens. At the same time, it is the principles of the legal status of a person, formed outside the very institution of the constitutional status of a person, that bring to it the meaning that necessitates truly historical changes in our society. Key words: constitutional status, legal status, constitutional and legal status of man and citizen, constitutional law, system of constitutional law, norm of constitutional law.

Раскрыта специфика нормы конституционного права Украины в контексте закрепления в ней основных положений конституционно-правового статуса личности и гражданина. Указывается, что многогранная система конституционного права и все ее структурные элементы состоят из норм конституционного права. Последние являются основой институтов конституционного права, а также других частей системы конституционного права - природного и положительного, общей и особой части, материально-правовой и процессуальной, международной и национальной. То есть система конституционного права Украины не может существовать вне своего нормативного измерения. Кроме того, право, а впоследствии и его система сформировались на основе правовых норм, исторически отличавшихся от других общественных норм - религиозных, моральных, этических, культурных и т.д. Отмечено, что положения общей теории конституционного права, исследования конституционно правового статуса человека и гражданина тес- 
но связаны с проблемой определения предмета конституционного права относительно правового статуса человека и гражданина. В связи с этим в науке конституционного права существует по меньшей мере два пути ответа на заданный вопрос. Один из них как предмет конституционного права истолковывает только основные принципы конституционно правового статуса человека, а другой к предмету науки конституционного права также добавляет проблемы защиты и поддержания конституционно правового статуса человека. человек и гражданин. Не считая того, освещение заморочек конституционно-правового статуса человека и гражданина имеет чисто методологическую актуальность. Учреждение Конституцией Украины основ правового статуса личности положило начало процессу образования нового типа правовой культуры нашего государства и его граждан. В то же время именно принципы правового статуса личности, сорормированные вне самого института конституционного статуса личности, вносят в нее тот смысл, который приводит к необходимости действительно исторических изменений в нашем обществе. Ключевые слова: правовой статус, конституционный статус, конституционно-правовой статус человека и гражданина, конституционное право, система конституционного права, норма конституционного права.

Розкрито специфріку норми конституційного права України в контексті закріплення в ній основних положень конституційно-правового статусу особи і громадянина. Вказується, що багатогранна система конституційного права України та всі їі структурні елементи складаються з норм конституційного права. Останні є основою інститутів конституційного права, а також інших частин системи конституційного права природного і позитивного, загальної та особливої частини, матеріально-правової та процесуальної, міжнародної та національної тощо. Тобто система конституційного права України не може існувати поза своїм нормативним виміром. Крім того, право, а згодом і його система сформувалися на основі правових норм, які історично вирізнялися з-поміж інших суспільних норм - релігійних, моральних, етичних, культурних тощо. Зазначено, що положення загальної теорії конституційного права, дослідження конституційно-правового статусу людини і громадянина тісно пов'язані з проблемою визначення предмета конституційного права щодо правового статусу людини ігромадянина. Уцьому сенсі в науці конституційного права існує щонайменше два шляхи відповіді на поставлене запитання. Один з них як предмет конституційного права тлумачить лише основні принципи конституційно-правового статусу людини, а інший до предмета науки конституційного права також додає проблеми захисту та підтримки конституційно-правового статусу людини. людина і громадянин. З іншого боку, висвітлення проблем конституційно-правового статусу людини і громадянина має суто методологічну актуальність. Заснування Конституцією України основ правового статусу особи поклало початок процесу утворення нового типу правової культури нашої держави та їі громадян. Водночас саме принципи правового статусу особи, сформовані поза самим інститутом конституційного статусу особи, вносять у неї той зміст, який зумовлює необхідність справді історичних змін у нашому суспільстві. Ключові слова: кправовий статус, конституційний статус, конституційно-правовий статус людини $і$ громадянина, конституційне право, система конституційного права, норма конституційного права.

Formulation of the problem. The primary and one of the most important elements of the system of constitutional law of Ukraine is the constitutional legal norm (from the Latin norma - rule, model). Norms of constitutional law as components of the system of constitutional law of Ukraine in their entirety reflect the essence and content of this branch of law. Given this, they are sometimes compared with cells, as the basis of any living organism, biological system.

According to V. Fedorenko, this comparison is true for many other organic systems. Thus, the multifaceted system of constitutional law of Ukraine and all its structural elements consist of the norms of constitutional law. The latter are the basis of the institutions of constitutional law, as well as other parts of the system of constitutional law - natural and positive, general and special part, substantive and procedural, international and national, and so on. That is, the system of constitutional law of Ukraine cannot exist outside its normative dimension. In addition, law, and later its system, were formed on the basis of legal norms, which have historically stood out from other social norms - religious, moral, ethical, cultural, and so on. In this case, the rules of law have retained the properties inherent in all social

\section{norms in general.}

Presenting main material. The content of the legal status of man is determined by all the norms and relations regulated by them that arise between the state and man in connection with its actual place in the socio-economic, political and spiritual-moral life of our society. These relations are very diverse, they cover various aspects of life and are therefore governed by the rules of not one, but almost all branches of law.

At the same time, constitutional norms play a special role here. Due to their general regulatory nature, they outline the position of citizens not in any one area of activity, but in its main areas. At the same time, they establish only the most essential, fundamental relations between the state and its citizens in connection with their place in the management of public and state affairs, leaving detailed regulation of such relations to the norms of other industries.

Any social norm, wrote the famous Ukrainian Soviet theorist of law P. Nedbaylo, is a rule of a general nature that reflects the needs of public life and is of guiding importance for the practical activities of people. Social norms arose simultaneously with 
human society in connection with the need to cover and regulate people's behavior by general rules. According to the scientist, "the norm is not a simple statement of facts, not a judgment about certain of their features, but a mandatory rule, a command that always requires certain results, the occurrence or non-occurrence of certain consequences. A norm is always a rule of proper and possible behavior within its limits, which obliges, forbids, allows this or that action or deed under certain conditions. The norm is an imperative that postulates a proper connection between people; it is caused by the threat of unfavorable consequences for anyone who deviates from its requirements». Such properties of the regulator of public relations are generally inherent in the norms of constitutional law.

Given the above-mentioned primacy of constitutional law on other structural elements of the multifaceted system of constitutional law of Ukraine, the study of their essence, content, legal properties and features of construction is a kind of «key» to knowledge of institutions and other components of constitutional law in general. In addition, unlike other structural elements of the system of constitutional law of Ukraine, the norms of constitutional law are one of the most studied in modern Ukrainian jurisprudence. Thus, only at the dissertation level the legal nature of the norms of the constitutional law of Ukraine has been studied several times in the last eighteen years (among such works, for example, the research of O. Stepaniuk; O. Sinkevych; J. Chistokolyany and others).

At the same time, the constitutional norms contain not only the initial data of the status of the person, but also fix all its main parties. Therefore, the constitutional status is rightly considered as the basis of the legal status of citizens.

It should be noted that the position of the general theory of constitutional law, the study of the constitutional and legal status of man and citizen is closely related to the problem of determining the subject of constitutional law on the legal status of man and citizen. In this sense, in the science of constitutional law, there are at least two ways to answer the question. One of them as a subject of constitutional law interprets only the basic principles of the constitutional and legal status of man, and the other to the subject of the science of constitutional law also adds the problems of protection and maintenance of the constitutional and legal status of man and citizen. On the other hand, the coverage of the problems of the constitutional and legal status of man and citizen has a purely methodological relevance. It means, according to T. Frantsuz-Yakovets, that due to the category of constitutional and legal status of man and citizen there is an opportunity to analyze its structure and constituent elements. In this case, the analysis acquires signs of complexity, because it examines not limited institutions of citizenship, legal personality, human rights and freedoms, responsibilities of citizens, guarantees of human rights and freedoms, etc., but one of the elements of the constitutional and legal status of man connected with others and forms a holistic system through which human relations with the state and other subjects of legal relations are established and regulated.

At the same time, according to the scientist, the problem of ensuring the constitutional and legal status of man and citizen is one of the key issues both in the science of constitutional law and in direct constitutional practice. This is due to the fact that the very concept of «constitutional and legal status of man and citizen» is fixing the foundations of the relationship between man, state and society, outlines their rights and mutual responsibilities, establishes a system of ensuring, guaranteeing and protecting the rights of all participants.

The task of studying the principle of equality of rights of women and men, as well as its scientific, theoretical and practical content, can not be limited to analysis of the actual rights of these categories of persons and other elements of their constitutional status, which are enshrined in law. Indeed, an adequate understanding of what in reality is the constitutional and legal status of man, provides a detailed coverage of the foundations through which the system of human and civil rights is formed and through which the actual implementation of these rights. These fundamental principles are defined by the concept of «principles of constitutional and legal status of man.» Their role and importance in the process of formation and development of relations between the state and the individual are explained by the fact that it is at the level of principles of constitutional and legal status of a person that determines whether the state ensures equality of human and civil rights and freedoms. defined in the Constitution of human rights and protect them, whether these rights are fully recognized by the state, whether there are restrictions on the exercise of human and civil rights, and if so, which, etc.

Thus, ipso jure, based on the understanding of the principles of constitutional and legal status of man as recognized and protected by law and the state basic principles on which the implementation of constitutional and legal status of man, it is necessary to recognize that the study of these principles and their specifics in the implementation of the constitutional and legal status of man, is an integral part of theoretical research in the field of constitutional law, the theory of human and civil rights.

According to the true statement of S. Lavrenyev, the importance of the institution of the constitutional status of a person in any modern democratic state is difficult to overestimate. In Ukraine, this is all the more difficult to do, because these institutes are 
associated not only with people's hopes for a decent legal way of life, but also with all the processes of transformation of the state and legal system of society. This is decisively explained by the fact that the constitutional status of a person has become the specific and legally significant form in which human rights and freedoms have found expression, which have determined and in many ways continue to be the most important cause of truly democratic changes in our society.

The establishment of the foundations of the legal status of a person by the Constitution of Ukraine marked the beginning of the process of compiling a new type of legal culture of our state and its citizens. At the same time, it is the principles of the legal status of a person, formed outside the very institution of the constitutional status of a person, that bring to it the meaning that necessitates truly historical changes in our society. Therefore, it is quite natural growth of scientific interest of constitutionalists to questions of sources, the nature and legal value of the basic principles of the constitutional status of the person.

Thus, in particular, P. Rabinovych, M. Khavronyuk, V. Kravchenko, O. Frytsky worked on the problem of the principles of the constitutional and legal status of a person and a citizen, which, in turn, highlight the following principles:

1) the principle of equality in rights and freedoms and equality before the law, which follows from Articles 21 and 24 of the Constitution of Ukraine;

2) the principle of inalienability and inviolability of human rights and freedoms, enshrined in Art. 21 of the Constitution of Ukraine;

3 ) the principle of guaranteeing the rights and freedoms of man and citizen and the impossibility of their abolition;

4) the principle of inexhaustibility of human and civil rights and freedoms, enshrined in Art. 22 of the Constitution of Ukraine;

5 ) the principle of compliance with international standards of human and civil rights and freedoms enshrined in the Constitution of Ukraine (Articles 3, $5,6,8,9)$;

6) the principle of unity of rights and responsibilities of man and citizen in accordance with Articles 23 and 68 of the Constitution of Ukraine.

In addition, some scholars highlight other principles of the constitutional and legal status of man and citizen. Thus, in particular, V. Kravchenko highlights the principle of human freedom. In his opinion, in Articles 21 and 23 of the Constitution of Ukraine, this principle determines her right to the free development of her personality, and the limit of individual freedom is the rights and freedoms of others. The scientist also highlights the principle of equality of people in their dignity (Article 21 of the Constitution of Ukraine). According to the Preamble of the International Covenant on Civil and Political Rights, the dignity of the person is a property inherent in "all members of the human family», recognition of human dignity, their equal and inalienable rights is «the basis of freedom, justice and universal peace».

P. Rabinovych and M. Khavronyuk in their work note a separate principle of the principle of preventing the narrowing of the content and scope of existing rights and freedoms, enshrined in Art. 22 of the Constitution, which does not allow narrowing when adopting new laws or amending existing laws. Also note the principle of prohibition of arbitrary restriction of constitutional rights and freedoms of human and citizen. Article 64 of the Constitution of Ukraine provides for the existence of certain formal limits to these rights and freedoms, and the fact that these limits must be determined only by law, only in cases provided by the Basic Law of Ukraine, and justified by relevant factors.

Finally, the principle enshrined in the Basic Law of our state (Articles 24, 23, 21), the principle of equality of rights of women and men (gender equality), which, in particular, declares that equality of rights of women and men is ensured by: providing women with equal rights. men opportunities in socio-political and cultural activities, in education and training, in work and remuneration for it.

Constitution. Without denying either the epistemological or practical value of the above approach to understanding and identifying the basic principles of the constitutional status of the person, it is impossible not to notice its one-sidedness. This is manifested, in the opinion of S. Lavrentyev already in the fact that such principles are universally recognized, and therefore, firstly, are not given by the state, but recognized by it, and secondly, are not formulated by the state and its bodies, and the international community, thus bringing to the constitutional status of the person universal values of natural rights and freedoms. Hence, according to A. Oliynyk, it follows that the methodology of their scientific analysis can not be reduced to the above rules. It should be extended to the naturallegal nature of the constitutional status of a person. This, in turn, makes it necessary to rethink both the category of "constitutional status of the person» and its structural entities, in a number of which are these principles.

\section{REFERENCES:}

1. Pogorilko V. F. (2006) Konstituczijne pravo Ukrayini : akad. kurs : pidruch. : u 2 t. T. 1 / za red. V. F. Pogori lka. K. : TOV «Vid-vo «Yuridichna dumka». 544 s. [in Ukrainian]

2. Fedorenko, Vladislav Leonidovich (2010) Teoretichni osnovi sistemi konstituczi jnogo prava Ukrayini. Dis. na zdobuttya nauk. stupenya dokt. yuridich. nauk: speczi'al'ni'st' 12.00 .02 - «konstituczi'jne pravo; muni'czipal'ne pravo». Kh., 2010. 550 s. [in Ukrainian] 
3. Nedbajlo P. O. (2004) Sovetskie soczialisticheskie pravovy`e normy`. Antologi ya ukrayins`koyi yuridichnoyi dumki : v 10 t. / [redkol.: Yu. S. Shemshuchenko (golova) ta i’n.]. T. 9 : Yuridichna nauka radyans koyi dobi / [uporyad.: V. B. Aver'yanov, O. M. Kostenko, V. P. Nagrebel'nij, V. F. Pogori’ lko, K. O. Savchuk, I'. B. Usenko, G. P. Timchenko; vi’dp. red. V. P. Nagrebel`nij]. K. : «Vidavnichij di’m «Yuridichna koniga», S. 73-95. [in Ukrainian]

4. Stepanyuk O. I. (1993) Normi konstituczi jnogo prava Ukrayini: problemi teori yi : avtoref. dis. na zdobuttya nauk. stupenya kand. yurid. nauk : specz. 12.00.02 «Konstituczi 'jne pravo Ukrayini». K. 18 s. [in Ukrainian]

5. Sinkevich O. V. (2003) Normi konstituczi jnogo prava Ukrayini : avtoref. dis. na zdobuttya nauk. stupenya kand. yurid. nauk : specz. 12.00.02 «Konstituczi jne pravo Ukrayini». K., 20 s. [in Ukrainian]

6. Chistokolyanij Ya. V. (2005) Konstituczi jno-pravovi' normi v Ukrayini' : avtoref. dis. na zdobuttya nauk. stupenya kand. yurid. nauk : specz. 12.00.02 «Konstituczi jne pravo Ukrayini». K., 20 s. [in Ukrainian]

7. Voevodin L.D. (1980) Ponyatie i osnovny`e e`lementy` konstituczionnogo statusa lichnosti. Konstituczionny`j status lichnosti v SSSR. M. Yurid. lit. $331 \mathrm{~s}$. [in Russian]

8. Franczuz-Yakovecz’ T. A. (2007) Zabezpechennya konstituczi jno-pravovogo statusu lyudini i’ gromadyanina v Ukrayini': Dis. nauk. stupenya kand. yurid. nauk za specz. 12.00.02. - konstituczi'jne pravo. Odes'ka naczi 'onal'na yuridichna akademi ya, Odesa. $210 \mathrm{~s}$. [in Ukrainian]

9. Lavrent'ev S.V. (2005) Osnovny'e princzipy` konstituczionnogo statusa lichnosti : Teoretiko-konstituczionny`j analiz: avtoref. disss. kand. yurid. nauk po specz. : 12.00 .02 - konstituczionnoe pravo; municzy' pal'noe pravo. Volgograd. $19 \mathrm{~s}$. [in Russian]

10. Rabinovich P. M., Khavronyuk M. I. (2004) Prava Iyudini i’ gromadyanina: Navchal’nij posi'bnik. K.: Ati'ka, 464 s. [in Ukrainian]

11. Kravchenko V.V. (2004) Konstituczi' jne pravo Ukrayini: Navchal'nij posi' bnik. K.: Ati'ka, $512 \mathrm{~s}$. [in Ukrainian]

12. Fricz'kij O. F. (2002) Konstituczi 'jne pravo Ukrayini: Pi'druchnik. K.: Yuri'nkom I’nter, 536 s. [in Ukrainian]

13. Mi'zhnarodnij pakt pro gromads 'ki' i' poli' tichni' prava. (1989) Prava lyudini (Osnovni' mi zhnarodno-pravovi' dokumenti). K. 530 s. [in Ukrainian]

14. Oli'jnikA.S. (2001) Konstituczi jne zakonodavstvo Ukrayini: Genderna ekspertiza. K.: Logos. 77 s. [in Ukrainian]

15. Byelov D. (2018) Human rights for information in social networks: constitutional aspect. Journal of legal studies. Volume 22. Issue 36. [in Ukrainian]

16. Byelov D.M., Gromovchuk M.V. (2017) Sistema zakhistu prav i’ svobod lyudini i' gromadyanina: doktirinal'ni' zasadi. Naukovij vi 'snik UzhNU. Seri 'ya "Pravo". Vipusk 42. C. 27-31. [in Ukrainian]

17. Byelov Dmytry. Ochrana l'udských a občianskych práv a slobôd advokácie na Ukrajine. L'UDSKÉ PRÁVA VČERA A DNES. PÔVOD A VÝZNAM L'UDSKÝCH PRÁV A ICH OCHRANA V PRÁVNEJ TEÓRII I PRAXI : Medzinárodná vedecká konferencia „Banskobystrická škola právnych dejín“ 3. ročník (Univerzita Mateja Bela, Právnická fakulta BANSKÁ BYSTRICA, 15. - 16. marca 2017). S. 15-19. [in Slovakian]

18. Byelov Dmytry, Hromovhcuk Miroslava. (2017) The constitution of the state in the context of its functions. Visegrad Journal on Human Rights. № 4. S. 41-49. [in Ukrainian]. 